\title{
Tomographic, hydrochemical and isotopic investigations of the salinization processes in the oasis shallow aquifers, Nefzaoua region, southwestern Tunisia
}

\author{
Zohra Kraiem $^{1, *}$, Najiba Chkir ${ }^{2}$, Kamel Zouari ${ }^{1}$, Jean Claude Parisot ${ }^{3}$, \\ Aissa AgOun ${ }^{4}$ and Daniel Hermitte ${ }^{5}$ \\ ${ }^{1}$ National School of Engineers of Sfax, Laboratory of Radio-Analyses and Environment, BP 1173, \\ 3038 Sfax, Tunisia. \\ ${ }^{2}$ Department of Geography, Laboratory of Radio-Analyses and Environment, BP 1168, 3002 Sfax, Tunisia. \\ ${ }^{3}$ CEREGE, UMR IRD 161, Technopôle de l'Environnement Arbois Méditerranée, Domaine du Petit Arbois, \\ Avenue Louis Philibert, BP 80, 13545 Aix en Provence Cedex 04, France. \\ ${ }^{4}$ Commissariat Régional au Développement Agricole (CRDA) de Kébili, Tunisie. \\ ${ }^{5}$ CEREGE, UMR 6635, CEREGE, BP 80, 13545 Aix en Provence Cedex 04, France. \\ ${ }^{*}$ Corresponding author. e-mail: kraiemzohra@yahoo.fr
}

An electrical imaging tomography survey was carried out to identify the lateral and vertical salinity distribution in the oasis shallow aquifers of the Nefzaoua region located in southwestern Tunisia. In addition, hydrochemical and isotopic data were examined to determine the main factors and mechanisms controlling the groundwater chemistry and salinity. Locally, with respect to salinization processes, electrical imaging tomography results show that the storage basins of irrigation excess-water contribute to the increase of the salinity for the major part of the oasis nearby these basins. Major elements distribution and saturation indices indicate that dissolution of evaporites (halite, anhydrite and gypsum) is the main process controlling the groundwater mineralization. Isotopic data highlighted the effect of evaporation in the salinization of these waters. The correlation between the oxygen 18 and the chlorides data confirms the importance of evaporation effect and dissolution as main processes controlling the groundwater mineralization.

\section{Introduction}

The management of fresh water reserves has become increasingly imperative for the sustainable management of natural resources. This is even more vital in arid zones where water resource scarcity is exacerbated by water quality degradation due to natural and human causes.

In most of the coastal aquifers, groundwater salinization processes are easily attributed to lateral seawater intrusion (Fedregoni et al. 2001;
Grassi et al. 2007; Ben Hamouda et al. 2010). However, for continental aquifers, when completely disconnected from the sea, multiple processes could be considered such as flow of saline groundwater from adjacent or underlying aquifers, anthropogenic contamination due to agriculture return flow, natural factors like dissolution of halite and gypsum and concentration by evaporation effect (Brouste et al. 1997; Stigter et al. 1998; Bennetts et al. 2006; Kacimov and Obnosov 2006; Matthew and Keith 2010). Consequently, several methods

Keywords. Tomography; drainage; dissolution; evaporation; oasis; salinization. 
could be used to investigate groundwater salinization such as geochemical methods based on salinity variations, cations and anions concentration distribution and/or isotopic tools. Electrical Resistivity Tomography (ERT) is one of the geophysical methods that could be used to achieve these objectives (Beauvais et al. 1999; Bauer et al. 2006; El Yaouti et al. 2008; De Franco et al. 2009). The ERT has recently become the most useful method in mapping the electrical conductivity of the subsurface (Griffiths and Barker 1993), since it allows to image groundwater salinity with spatial resolution. Taking into account the fact that the formation resistivity measured by ERT strongly depends on the groundwater salinity, this method has been used to indicate the subsurface salts movements (White 1988; Bevc and Morrison 1991; Kemna et al. 2002), to demonstrate seawater intrusion (Kruse et al. 1998; Nowroozi et al. 1999) and to delineate the contamination with pollutants (Osiensky and Donaldson 1995; Benson et al. 1996; Atekwana et al. 2000; De la Vega et al. 2003). In this study, both geochemical and geophysical approaches are introduced to improve the understanding of mineralization processes, the spatial distribution of salinization and also to obtain a more comprehensive overview of this phenomenon.

This study has been carried out on two sites of the Nefzaoua region, southwestern Tunisia, the Douz oasis and the Kebili oasis regions, considered as representative of oasis agriculture practices for water management. In terms of water resources, phreatic oasis aquifers are of secondary importance due to their high salinity of 2000 to more than $10,000 \mathrm{mg} / \mathrm{l}$ of total dissolved solids (El-Fahem 2003; Seigfried 2004; Zammouri et al. 2007) but should be better sustained in a region where water scarcity is the main constraint against socio-economical development.

The aim of this paper is to demonstrate the origins of mineralization and to determine the mechanisms controlling the spatial distribution of salinization in the oasis shallow aquifers of the Nefzaoua region by coupling ERT and geochemical methods.

\section{Site description}

The Nefzaoua region is located in southwest of Tunisia between longitudes $8^{\circ} \mathrm{E}$ and $9^{\circ} 30^{\prime} \mathrm{E}$ and latitudes $33^{\circ} \mathrm{N}$ and $33^{\circ} 40^{\prime} \mathrm{N}$, covering an area of approximately $1900 \mathrm{~km}^{2}$ with an average altitude of $50 \mathrm{~m}$. This region is bounded to the west by the hypersaline depression of Chott Djerid, to the north by the Tebaga mountain ranges, to the east by the Dahar mountain ranges and to the south it opens on the Grand Erg Oriental (figure 1). The climate is arid to hyper-arid influenced by dry and hot air masses coming from the desert. Precipitations are rare and irregular with less than $100 \mathrm{~mm}$ per year of average and marked by high temporal and spatial variability. Daily mean temperatures vary between $10^{\circ} \mathrm{C}$ in the winter to $32^{\circ} \mathrm{C}$ in the summer, August being the hottest month. Yearly open water evaporation ranges about $2500 \mathrm{~mm}$ (El-Fahem 2003; Mamou 1990) and averages to $1700 \mathrm{~mm} /$ year in the oasis.

The Nefzaoua region is marked by the extension of agricultural oasis for date palms, along the shoreline of Chott Djerid. Irrigation is carried out according to submersion method where a certain level of water is supplied to the field to be irrigated until the soil is saturated and completely covered. This level of water is higher than the amount required by crops and induces an excess of water that should be drained. Irrigation water is withdrawn from two deep aquifers. The first one, the Complexe Terminal (CT), is underlying the shallow Plio-Quaternary aquifers and is characterized by a mean salinity of $3 \mathrm{~g} / \mathrm{l}$. The deeper second one, the Continental Intercalaire aquifer (CI), is less used and has an average salinity of $4 \mathrm{~g} / \mathrm{l}$. A part of the excess irrigation waters are stored in the Mio-Plio-Quaternary deposits and thus constitute the oasis shallow aquifers increasing the risks of hydromorphy and asphyxiation for the date palms. Remediation solutions consist of drainage systems that have been implanted to drain these waters along a drainage network towards open water storage basin outside the oasis. Indeed, the Nefzaoua region is characterized by an important upper layer of soil with a thickness exceeding $80 \mathrm{~cm}$. These sandy to clayey-sandy soils have high permeability and porosity and more than $5 \%$ slope. Due to continuous leaching of soils, waters become charged out with salts and their percolation to the underlying oasis shallow aquifers constitute a hypersaline water intrusion threat.

Geology of the Nefzaoua region consists of a sedimentary succession extending from lower to upper Cretaceous formations outcropping in the Tebaga and Dahar mountain ranges while most of the region is covered by Mio-Plio-Quaternary deposits (figure 1). The Mio-Pliocene formations are continental with typical features including a median layer framed by two sandy terms. The top sandy term extends all over the studied region and lodges the shallow aquifers. The median clayey layer has a variable thickness that can reach 100 meters near Chott Djerid and constitute the bottom of the shallow aquifers (Mamou 1979). The Chott Djerid is a playa system in a subsidence basin covering an area of $5400 \mathrm{~km}^{2}$ characterized by highly salinized waters, often exceeding $100 \mathrm{mg} / \mathrm{l}$ of dissolved salts (Gueddari 1980). 

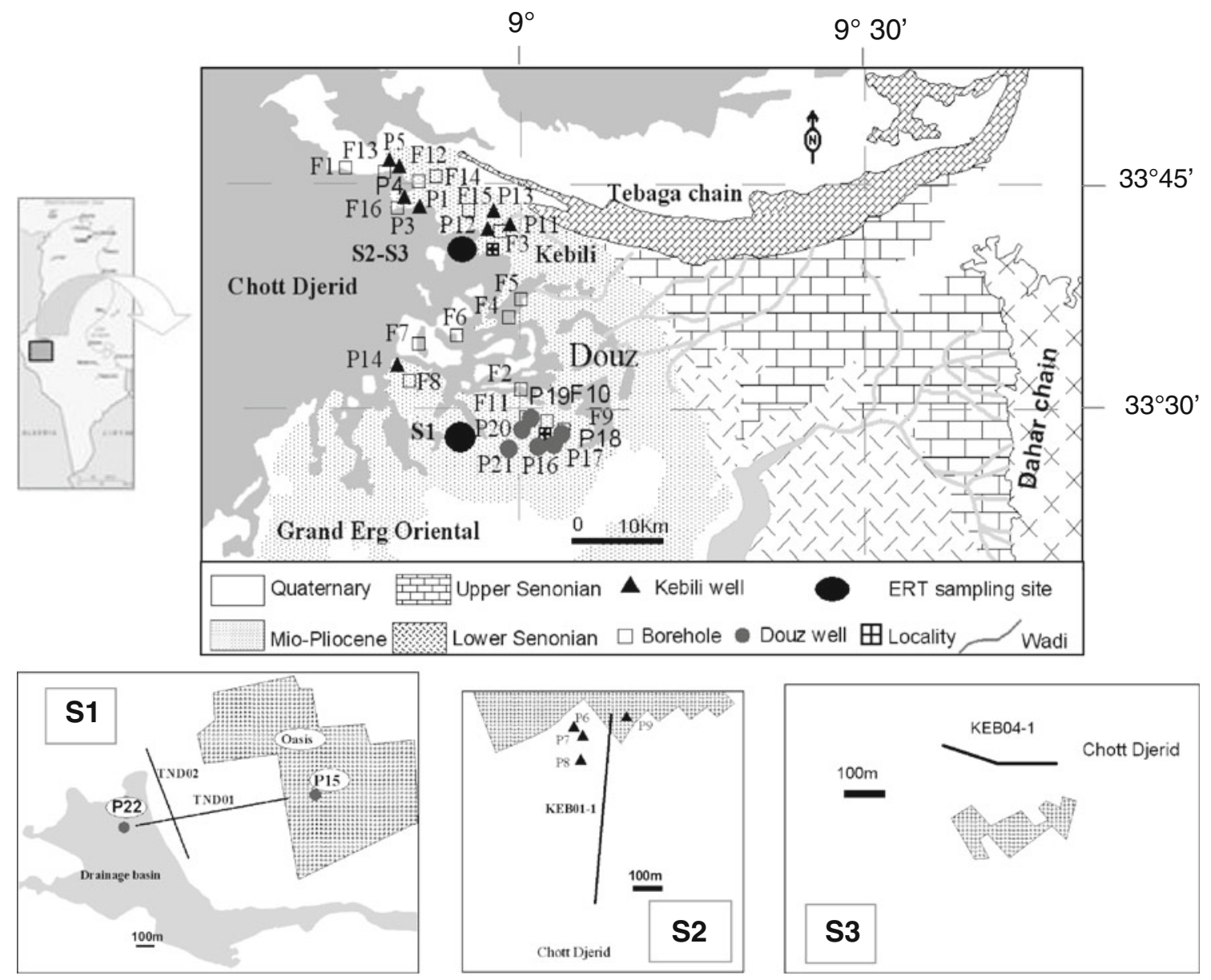

Figure 1. Geographical and geological map of the Nefzaoua region.

Previous hydrogeologic studies identified lenticular multilayered aquifers in the Nefzaoua region (Mamou 1979, 1990). Shallow aquifer levels are found in the Mio-Plio-Quaternary sediments and in the alluvial fillings of the wadis. In this study, we focused on some phreatic aquifers mainly recharged by irrigation return flow along the Chott Djerid where oasis systems are concentrated. Underlying these formations were deposited the Complexe Terminal formations. The term Complexe Terminal describes a multi-layer aquifer which consists of the Upper Cretaceous formations or Senonian limestones in the northern Saharan basin. In the Nefzaoua oasis region, the thickness of the $\mathrm{CT}$ varies between $100 \mathrm{~m}$ in the northeast and $400 \mathrm{~m}$ towards the southwest.

\section{Materials and methods}

Resistivity data were recorded using an ABEM computer-controlled multichannel resistivity meter with an array of 64 steel electrodes in a straight line according to a Wenner-Schlumberger configuration with a constant $5 \mathrm{~m}$ electrode spacing to obtain deep information (until 30-40 m). Data are presented as pseudo-sections (Edwards 1977), giving an approximate image of the subsurface resistivity. Field surveys were inverted using the robust constrained method in order to enhance local heterogeneities (Loke 1999; Savin et al. 2002), incorporating topographic variations. The resulting pseudo sections of apparent resistivity do not necessarily indicate gradual change in resistivity requiring a careful comparison of the resistivity data with available core logging data.

This method was undertaken on three sites at the border east of Chott Djerid (figure 1). The first site $\mathrm{S} 1$ is in the south of the Douz region with two perpendicular profiles: an east-west profile from the border of the oasis to the drainage basin (TND01) and a north-south profile (TND02). The second site $\mathrm{S} 2$ is in the Kebili region with a north-south profile from the border of the oasis towards the Chott Djerid (KEB01). The third site S3 is located in the Kebili region down in the Chott Djerid depression with a west-east profile (KEB04).

In addition, in April 2010, a total of 19 samples were collected from wells in the oasis shallow aquifers of Douz and Kebili regions at depths 


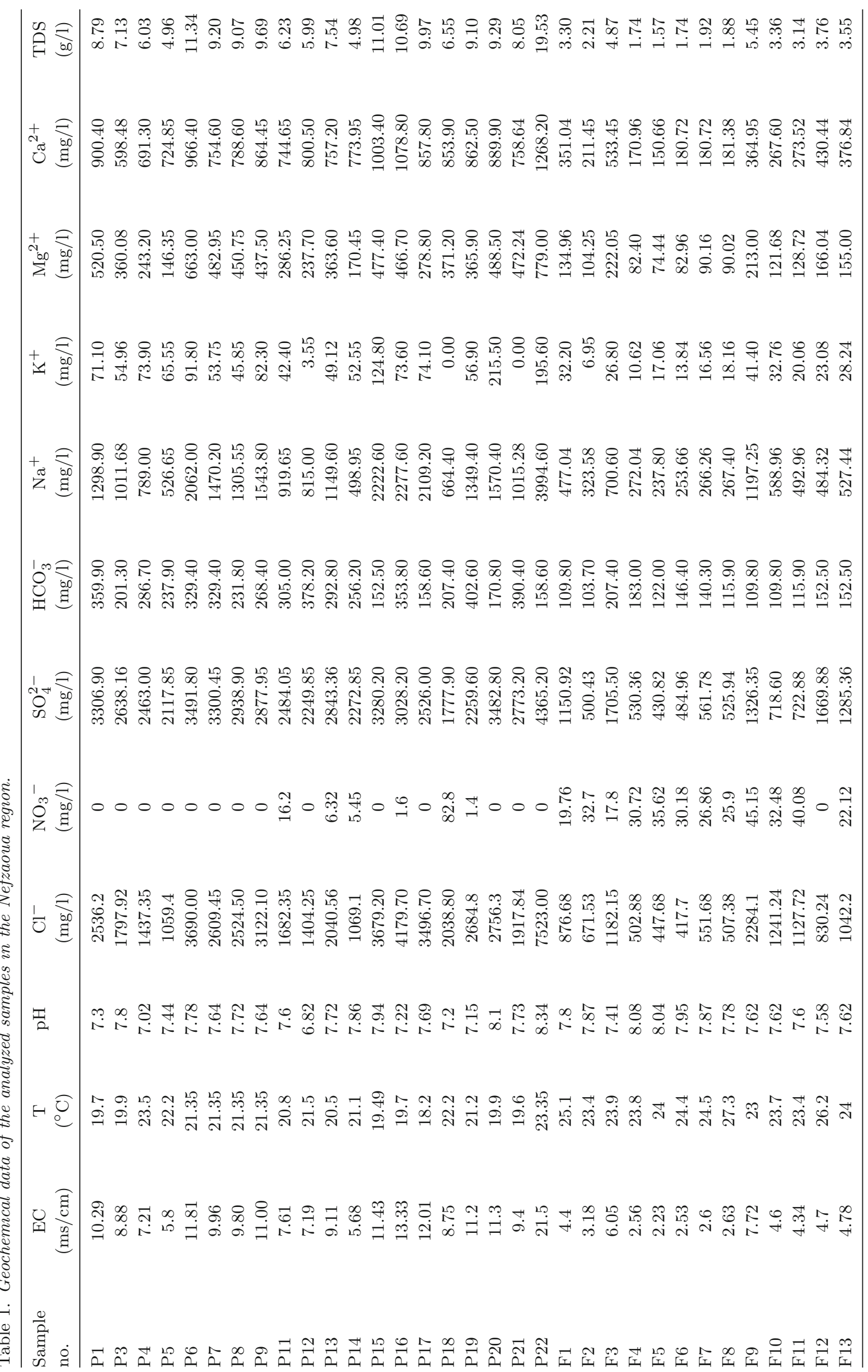




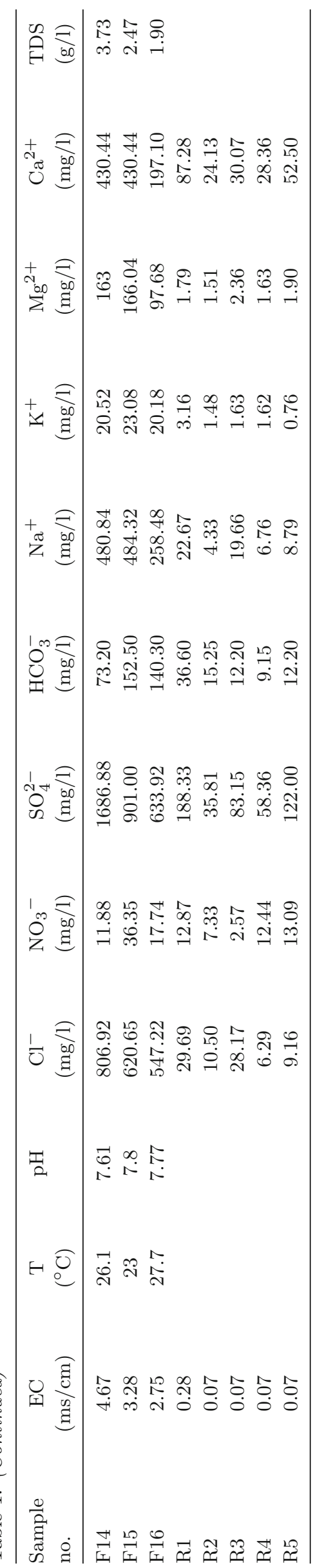

ranging between 4 and 15 meters, 16 samples were collected from the underlying aquifer of the Complex Terminal, a sample has been taken from the drainage basin (P22) (figure 1) and the signature of the precipitation in the region has been established on 5 samples (representing the years of 2008 and 2009) (table 1). Physical parameters, pH, temperature and electrical conductivity (EC), were performed in the field. Major element concentrations $\left(\mathrm{Ca}^{2+}, \mathrm{Mg}^{2+}, \mathrm{Na}^{+}, \mathrm{Cl}^{-}, \mathrm{SO}_{4}^{2-}, \mathrm{K}^{+}\right.$, and $\mathrm{HCO}_{3}^{-}$) have been done, for all the samples, by standard ion chromatography technique with a measurement precision of $0.04 \mathrm{mg} / \mathrm{l}$. TDS represent the total dissolved salts noticed in the laboratory. Its determination consists to evaporate, for 24 hours in an oven at $105^{\circ} \mathrm{C}, 100 \mathrm{ml}$ of sample water. It corresponds to the mass difference and is expressed in $\mathrm{g} / \mathrm{l}$.

Stable isotopes $\left({ }^{18} \mathrm{O},{ }^{2} \mathrm{H}\right)$ were measured by laser spectrometry and reported in the usual $\delta$ notation relative to Vienna Standard Mean Oceanic Water (VSMOW, where $\delta=\left[\left(\mathrm{R}_{\mathrm{S}} / \mathrm{R}_{\mathrm{SMOW}}\right)-1\right]-1000$; $\mathrm{R}_{\mathrm{S}}$ represents either the ${ }^{18} \mathrm{O} /{ }^{16} \mathrm{O}$ or the ${ }^{2} \mathrm{H} /{ }^{1} \mathrm{H}$ ratio of the sample, and $\mathrm{R}_{\text {SMOW }}$ is ${ }^{18} \mathrm{O} /{ }^{16} \mathrm{O}$ or the ${ }^{2} \mathrm{H} /{ }^{1} \mathrm{H}$ ratio of the SMOW). Typical precisions are $\pm 0.1 \%$ and $\pm 1.0 \%$ for the oxygen 18 and the deuterium, respectively. Eleven sampling points from the oasis shallow aquifers of Douz and Kebili regions, eight sampling points from the Complexe Terminal aquifer and five sampling points representing the rain waters were analyzed for the stable isotopes. Chemical and isotopic analyses were done in the Laboratory of Radio-Analysis and Environment in the National School of Engineers of Sfax (Tunisia).

\section{Results and discussions}

\subsection{Electrical tomography}

To demonstrate the effect of the irrigation and the effect of the Chott, ERT profiles were carried out in these regions. The results of the inversion of apparent resistivities measured along four profiles and their vertical and lateral variations were compared with many logging datasets of the boreholes nearest to the profiles.

For the first site, two profiles were carried out. The resistivity profile TND01 (figure 2) is calibrated with borehole (F6) taking into account the electrical conductivity of the water points (P15, P22). We showed that the shallow aquifer has a mean thickness of $13 \mathrm{~m}$. This aquifer is lodged in a sandy and sandy-clay horizons. Laterally and towards the west, resistivity decreases to values of $(0,33-1,01 \Omega \mathrm{m})$ reflecting the transfer of salty water from the drainage basin (figure 1, S1) into 


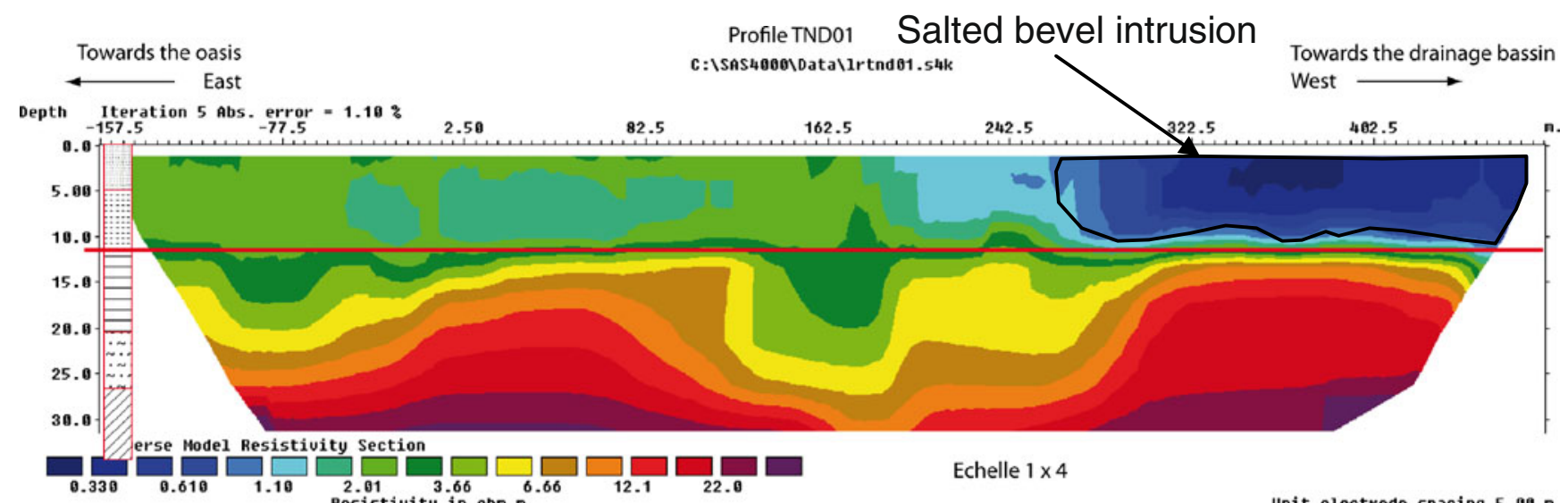

Sand

Figure 2. Cross-section of resistivity inversion results of profile TND01.

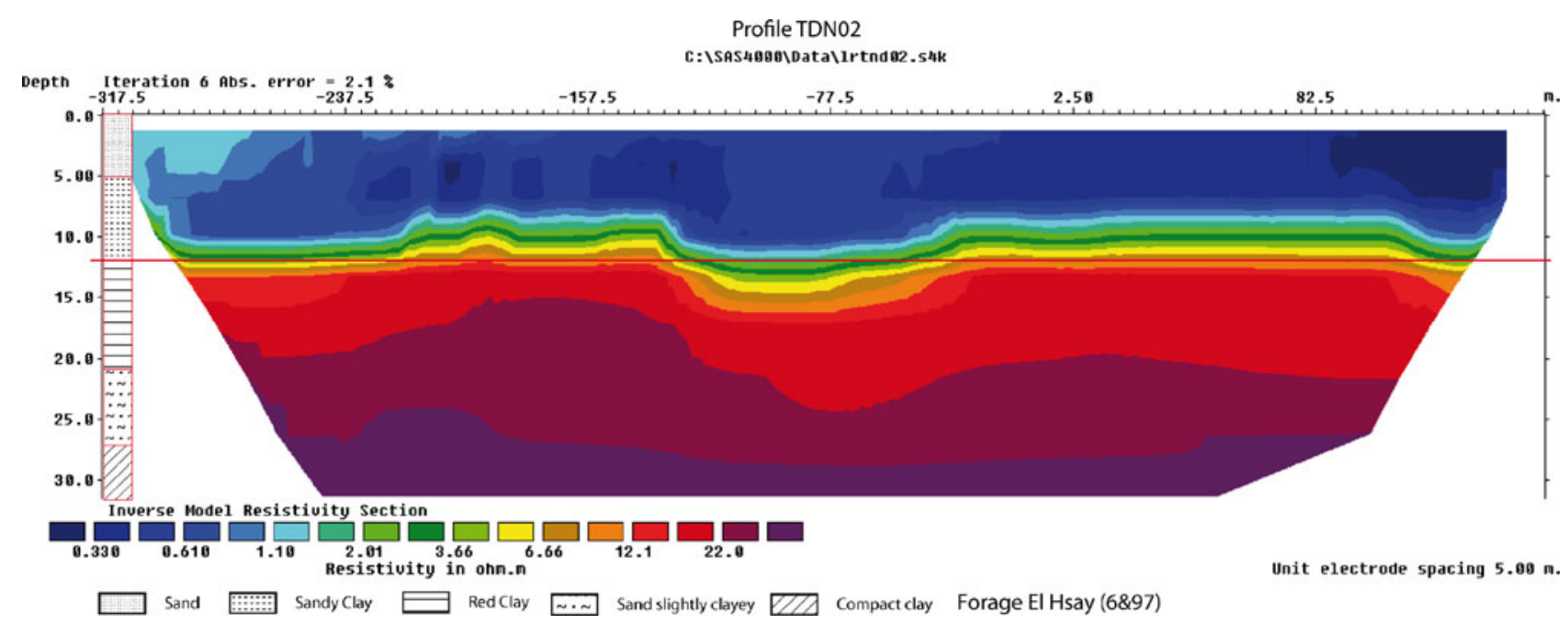

Figure 3. Cross-section of resistivity inversion results of profile TND02.

the oasis shallow aquifers. The wall is materialized by a lay down of clay over $30 \mathrm{~m}$ of depth.

Indeed, two distinguished zones were observed from west to east. The first is characterized by very low values of resistivities $(0,33-1,5 \Omega \mathrm{m})$. It defined the zone impacted by the drainage basin and confirmed an intrusion of a salted bevel. Another zone presents slightly higher values of resistivities $(2 \Omega \mathrm{m})$ with some weaker local values. To the middle of the profile, a depression is noticed by values of resistivity between 5 and $6 \Omega \mathrm{m}$. It could be explained by the existence of an old channel observed in the study area.

The resistivity profile TND02 (figure 3) is chosen orthogonal to the previous one. Thus, in the shallow aquifers, there is an increase of resistivity from the south to the north along the profile indicating the limit between the lake and the sand dunes (towards $80 \mathrm{~m}$ ). But this increase of resistivity is accompanied by a heterogeneous spatial distribution of the salinity.

The second and the third sites are chosen in the Kebili region. The resistivity profiles KEB01 (figure 4) and KEB04 (figure 5) are calibrated with the Kebili 2006 borehole and with electrical conductivities of water points located near these profiles (P6, P7 and P8). The first resistivity profile KEB01 shows three distinct electrolayers. A layer with a mean thickness in average of $11 \mathrm{~m}$, essentially constituted of red clayey sands and corresponding to the top part of the shallow aquifer. From the oasis to the Chott, some high resistivities in relation with the infiltration of the fresh irrigation water are recorded near the oasis but decrease towards the Chott. The second electrolayer, corresponding to a green clayey sands level, has a mean thickness of $14 \mathrm{~m}$ with low resistivities $(1,01-2,01 \Omega \mathrm{m})$. This layer is well demonstrated 


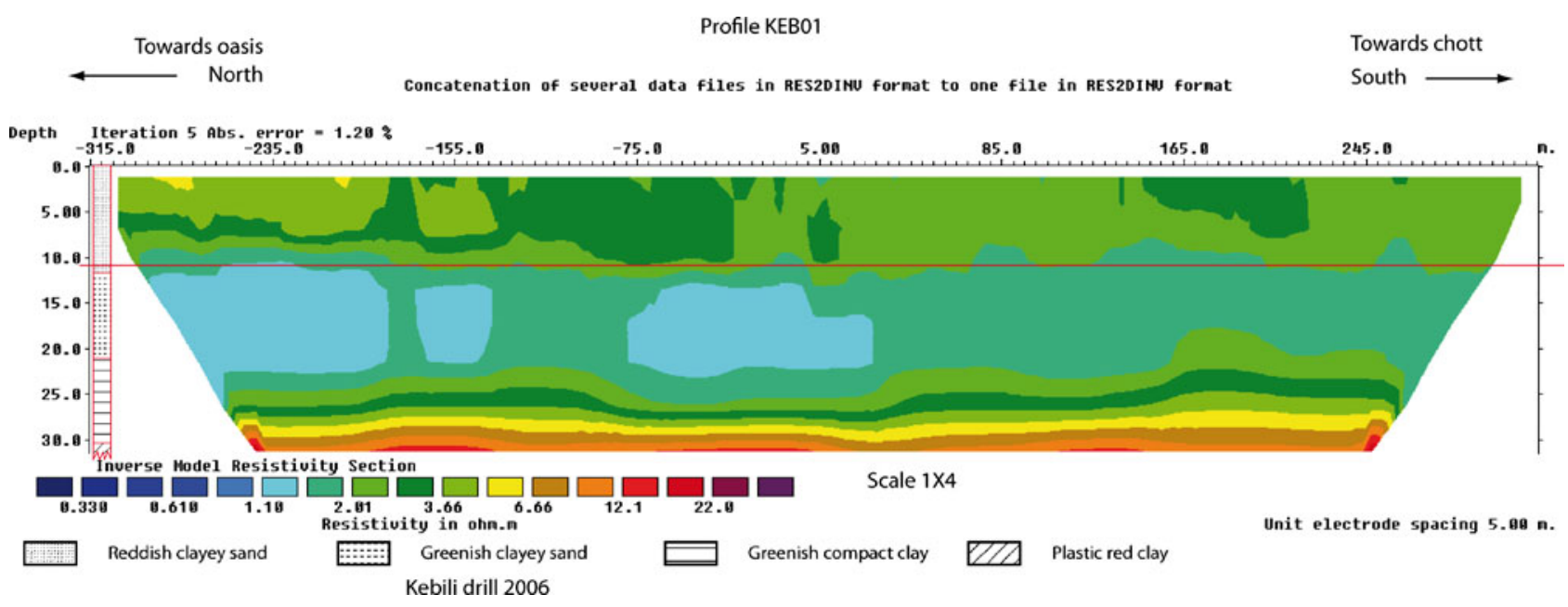

Figure 4. Cross-section of resistivity inversion results of KEB01.

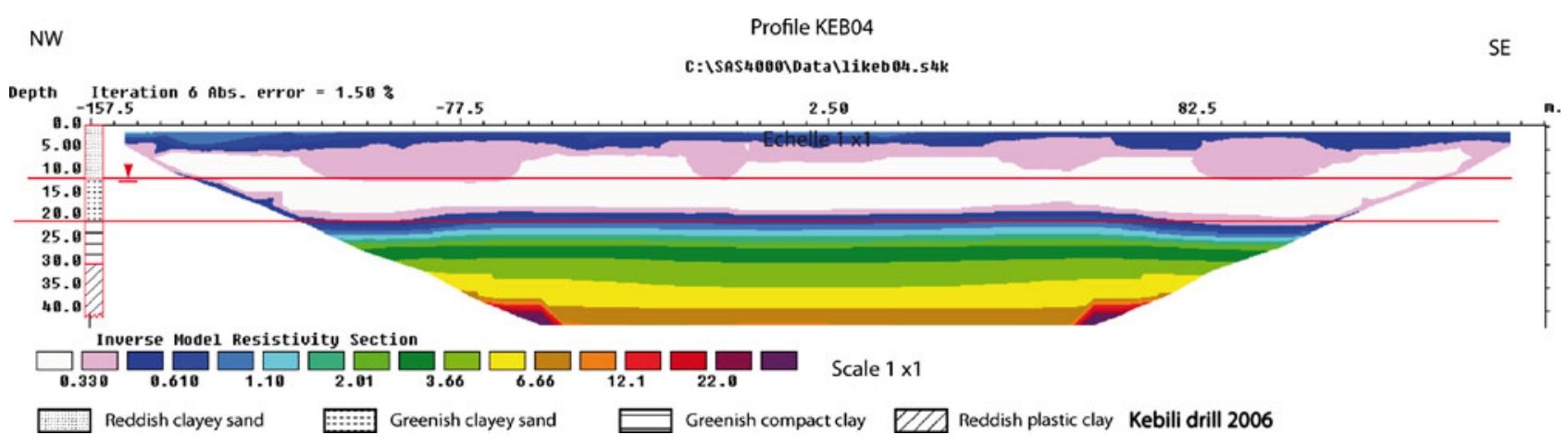

Figure 5. Cross-section of resistivity inversion results of KEB04.

in the resistivity profile KEB04 (figure 5). The decrease in resistivity can be explained by a decrease in porosity caused by the iron oxidation. It can also indicate that the shallow aquifer is too much charged in clay towards the Chott. Globally, the resistivity values are very low compared to those observed in the other resistivity profiles (KEB01) and they are essentially related to the clay contents. The third electrolayer is constituted of impermeable compact clay and forms the bottom of the shallow oasis aquifers.

In order to better understand the mechanisms of salinization affecting the shallow aquifers in the Nefzaoua oasis region, hydrochemical (physical parameters and major elements) and isotopic studies (stable isotopes) were carried out.

\subsection{Physical parameters}

The $\mathrm{pH}$, temperature, electrical conductivity (EC), total dissolved solids (TDS) and major ion concentrations for the groundwater samples of the Kebili and Douz regions are presented in table 1 . The
$\mathrm{pH}$ values of the water samples of the oasis shallow aquifers and the $\mathrm{CT}$ aquifer range from 6.82 to 8.1 and from 7.41 to 8.08 respectively, indicating an insignificant influence that may be the infiltration and/or the intrusion of drainage waters. Temperature ranges from $18.2^{\circ}$ to $23.5^{\circ} \mathrm{C}$ influenced by the atmosphere temperature. For the CT aquifer, temperature varies from $23^{\circ}$ to $27.7^{\circ} \mathrm{C}$, these high values could be explained by the influence of the mixing of waters by upcoming from the underlying aquifers of the Continental aquifer (CI) (Zammouri et al. 2007; Abid et al. 2011). The electrical conductivity (EC) varies largely between 5.68 and $13.33 \mathrm{~ms} / \mathrm{cm}$ for the oasis shallow aquifers and reaches $21.5 \mathrm{~ms} / \mathrm{cm}$ in the drainage basin (P22). For the CT aquifer, EC ranges from 2.23 to $7.72 \mathrm{~ms} / \mathrm{cm}$ highlighting several processes of mineralization in the study area.

The TDS values show a large range of variation for the oasis shallow and the CT aquifer (table 1). In the Kebili region, TDS varies between 4.96 and $11.34 \mathrm{~g} / \mathrm{l}$ with a mean salinity of $7.58 \mathrm{~g} / \mathrm{l}$. In the Douz region, it evolves from 6.55 to $11.01 \mathrm{~g} / \mathrm{l}$ with a mean salinity of $9.24 \mathrm{~g} / \mathrm{l}$. We can deduce that 
Douz oasis shallow aquifers are relatively high mineralized than those of Kebili region. Although, the proximity to the Chott Djerid, the Kebili oasis shallow aquifers are less mineralized and thus could be explained by the leaching of the drainage water into Chott. Nevertheless, in the Douz region, the drainage water is accumulated in basins in the shorelines of the oasis. Therefore the effect of drainage basins is more favoured (figure 6a). For the CT aquifer, the spatial distribution of the salinity indicates two zones with relatively high values which exceed $3.3 \mathrm{~g} / \mathrm{l}$. In the Kebili region, these high values could be explained by an upcoming of water from the underlying aquifers (Zammouri et al. 2007; Abid et al. 2011); whereas, in the Douz region, the high values could be explained by the infiltration of the drainage water on the shorelines of oasis.

\subsection{Major geochemical elements}

Plotted on the piper diagram (figure 7a), major elements reveal heterogeneous distribution. The cationic diagram (figure $7 \mathrm{~b}$ ) shows mixed facies with no dominant cation for the CT aquifer, the Douz and the Kebili oasis shallow aquifers. However, P17, P16, P15, P22, F9 and F10 constitute a pole with high content of sodium. They form the group of points situated in the Douz region and may be related to the influence of drainage water. In the anionic diagram (figure 7c), we show an evolution from a chloride pole formed by the points: P16, P17, P22, F2, F9, F10 and F11 situated in the Douz region to a sulphate pole constituted by P5, P14, F12 and F14 sampling points, situated in the Kebili region. This evolution could be explained by the effect of the lithological formations whether enriched in sulfates or halite minerals and/or the effect of drainage water. The facies of waters and the percentages of each element are illustrated in table 2 .

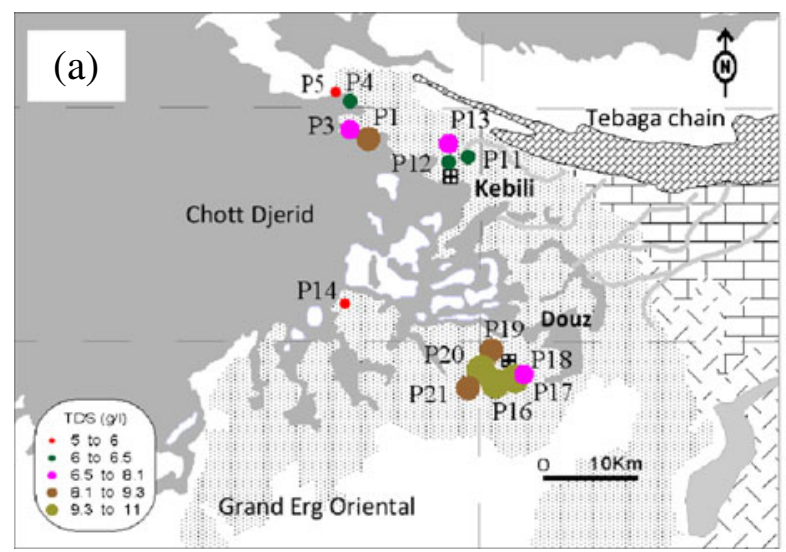

In order to identify the geochemical processes contributing to the groundwater salinization in the Kebili and Douz shallow aquifers, the major elements were plotted against TDS values (figure 8). These diagrams indicate a well defined correlation characterizing the relationship of $\mathrm{Na}^{+}, \mathrm{Cl}^{-}, \mathrm{Ca}^{2+}$, $\mathrm{SO}_{4}^{2-}, \mathrm{K}^{+}$and $\mathrm{Mg}^{2+}$ versus TDS values indicating that all the major elements contribute to the water mineralization.

In order to more highlight the mechanisms that contribute to groundwater mineralization, relationships between major elements were investigated. The $\mathrm{Na}^{+} / \mathrm{Cl}^{-}$relationship (figure 9), shows relatively high concentrations in $\mathrm{Na}^{+}$and ions $\mathrm{Cl}^{-}$which argue for the role of halite dissolution as a major process contributing to the groundwater mineralization (Appelo and Postma 1993). The deficit of $\mathrm{Na}^{+}$relative to $\mathrm{Cl}^{-}$indicates that the contribution of the halite dissolution to the groundwater salinization could be explained by the intervention of other processes like cation exchange. On the other hand, the positive correlation between $\mathrm{Ca}^{2+}$ and $\mathrm{SO}_{4}^{2-}$ and the enrichment of samples with $\mathrm{SO}_{4}^{2-}$ (figure 10), suggest the dissolution of anhydrite and/or gypsum as a principal source of salinization.

The $\mathrm{SO}_{4}^{2-} / \mathrm{Ca}^{2+}$ ratio is higher for the samples of Kebili and Douz oasis shallow aquifers. The excess of $\mathrm{SO}_{4}^{2-}$ over $\mathrm{Ca}^{2+}$ reflects extra sources of $\mathrm{SO}_{4}^{2-}$ and/or a deficit of $\mathrm{Ca}^{2+}$. The cation exchange and the calcite precipitation are suggested as the factors that remove the $\mathrm{Ca}^{2+}$ from the groundwater and decrease its content. $\mathrm{SO}_{4}^{2-}$ versus $\left(\mathrm{Ca}^{2+}+\mathrm{Mg}^{2+}\right)$ shows a good positive correlation (figure 11). Thus the deficiency of calcium is probably related to carbonate precipitation. Moreover, the referred cation-exchange probably generates a $\mathrm{Ca}^{2+}$ deficiency with respect to $\mathrm{SO}_{4}^{2-}$ concentration. This phenomenon is illustrated in the relationship between $\left(\mathrm{Na}^{+}+\mathrm{K}^{+}-\mathrm{Cl}^{-}\right)$and $\left(\mathrm{Ca}^{2+}+\right.$ $\left.\mathrm{Mg}^{2+}\right)-\left(\mathrm{HCO}_{3}^{-}+\mathrm{SO}_{4}^{2-}\right)$ (figure 12$)$, which varies

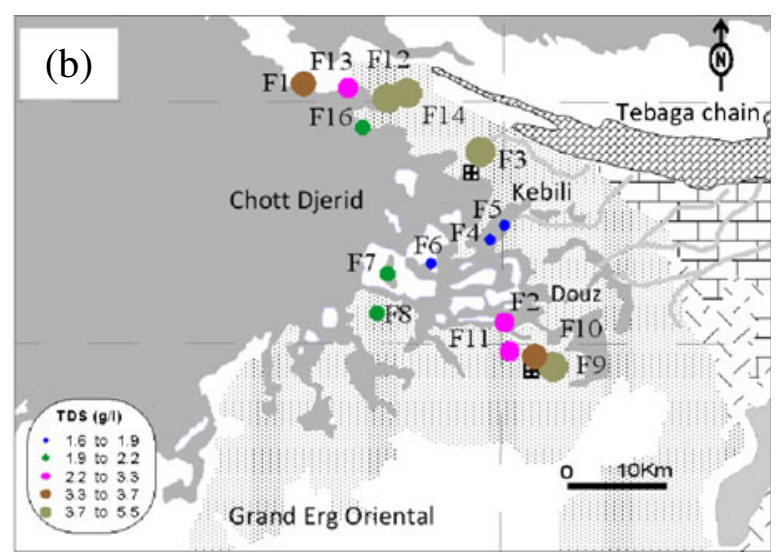

Figure 6. Spatial distribution of salinity of (a) oasis shallow aquifers and (b) CT aquifer. 

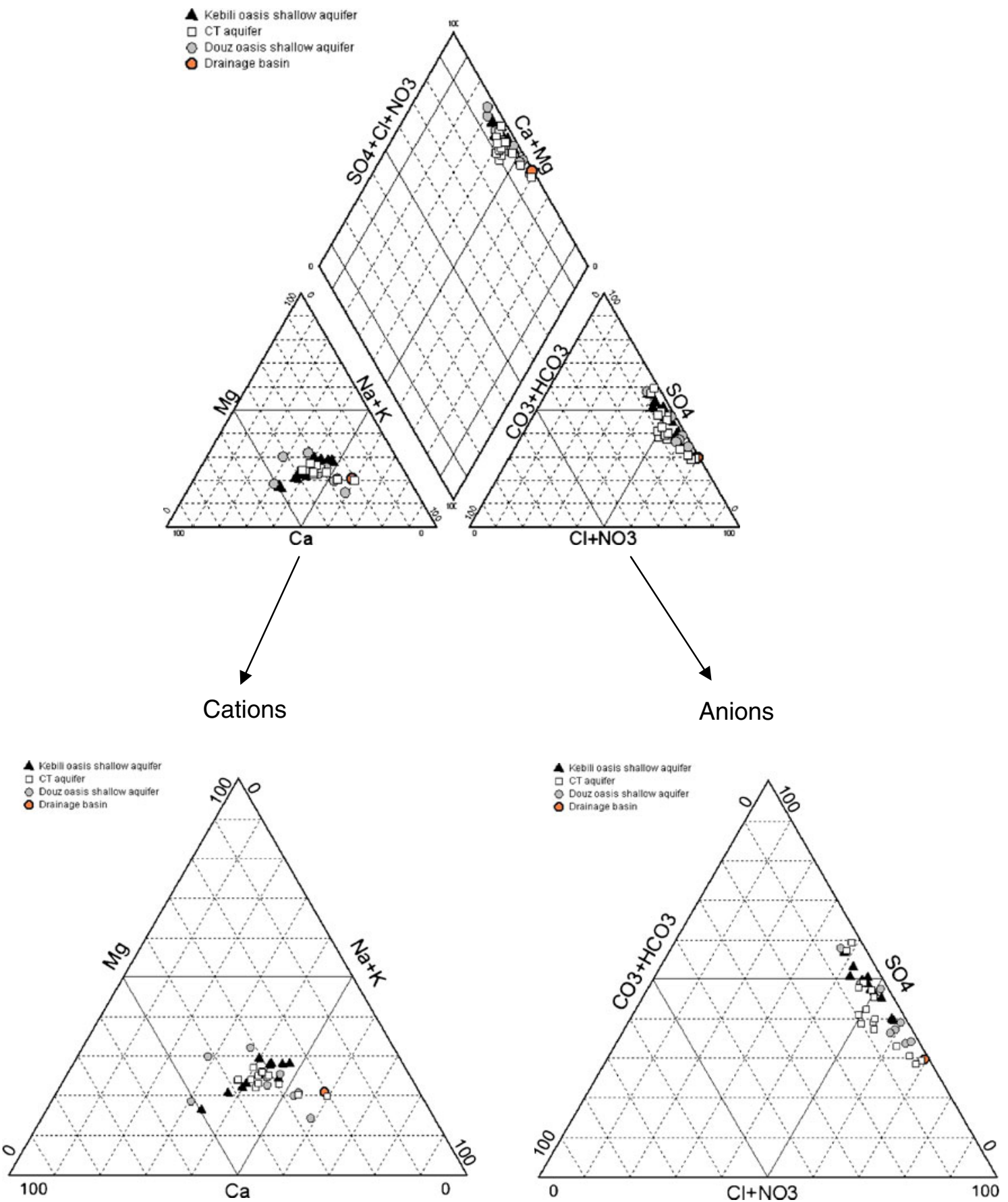

Figure 7. Piper diagram of the sampled groundwaters (a), cationic diagram (b) and anionic diagram (c).

Table 2. Water type characteristics of water groups.

\begin{tabular}{lccccc}
\hline & $\begin{array}{c}\mathrm{Na}^{+} \\
(\%)\end{array}$ & $\begin{array}{c}\mathrm{Ca}^{2+} \\
(\%)\end{array}$ & $\begin{array}{c}\mathrm{Cl}^{-} \\
(\%)\end{array}$ & $\begin{array}{c}\mathrm{SO}_{4}^{2-} \\
(\%)\end{array}$ & Water type \\
\hline Douz oasis shallow aquifer & 78 & 56 & 54 & 42 & $\mathrm{Na}-\mathrm{Ca}-\mathrm{Cl}$ \\
Kebili oasis shallow aquifer & 77 & 60 & 50 & 51 & Mixed \\
Drainage basin & 80 & 42 & 70 & 30 & $\mathrm{Na}-\mathrm{Cl}$ \\
CT aquifer & 76 & 51 & 53 & 44 & Mixed \\
\hline
\end{tabular}



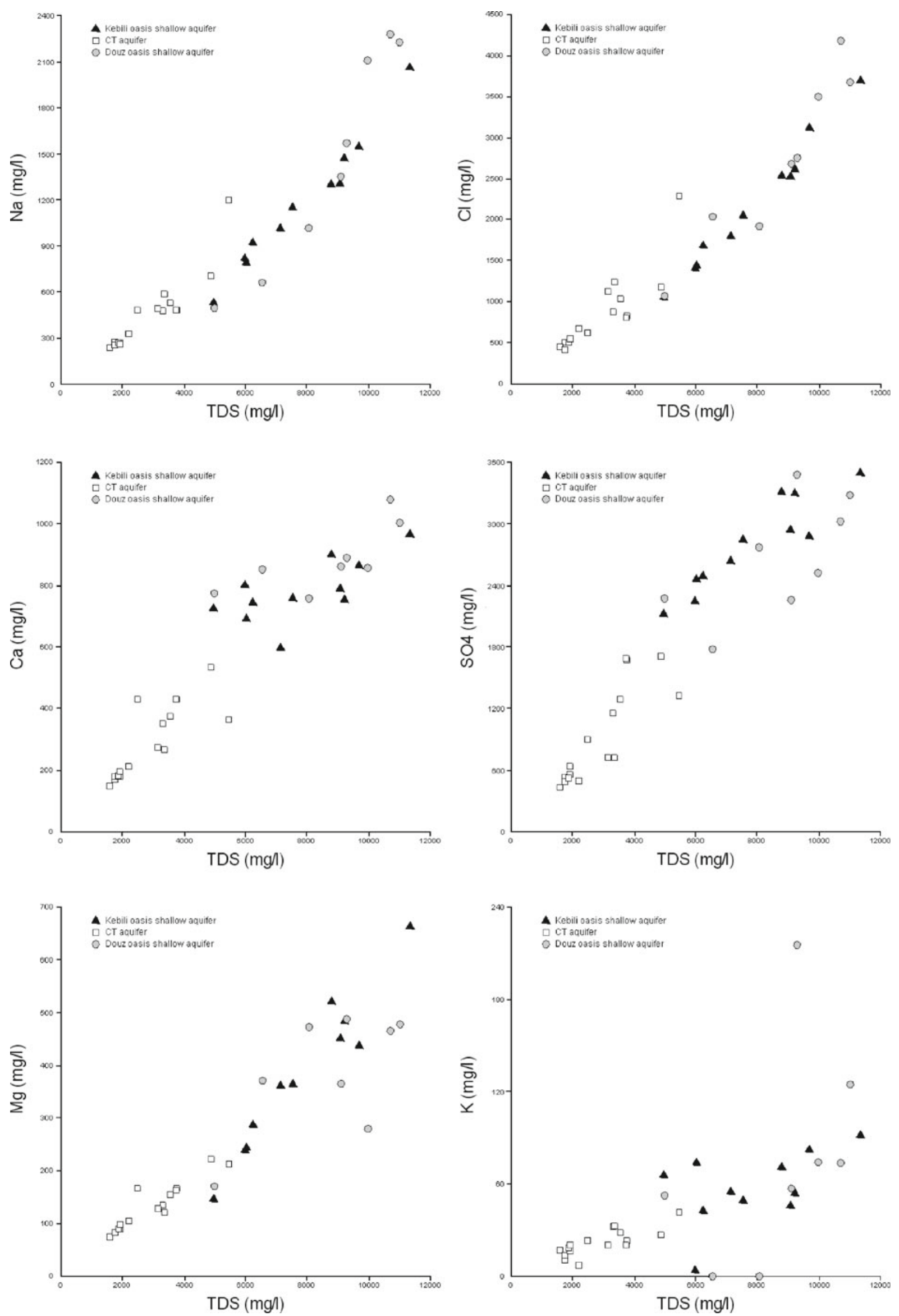

Figure 8. Major elements versus TDS relationships. 


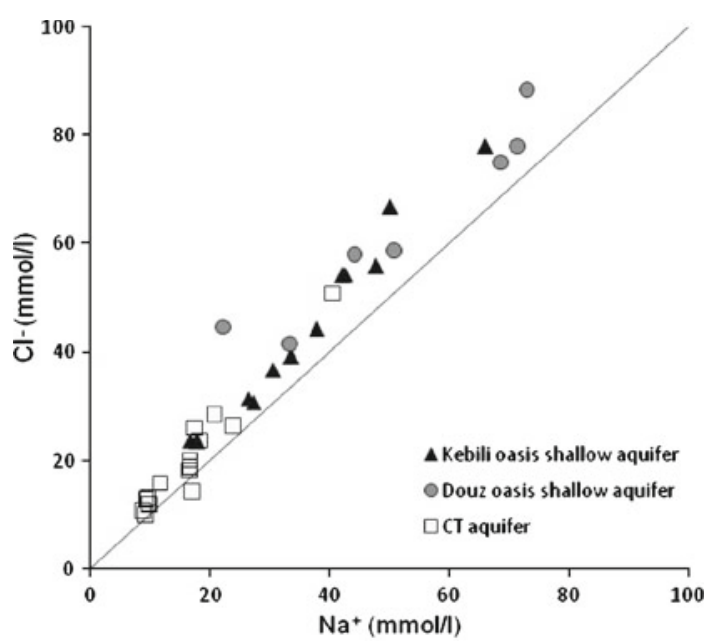

Figure 9. $\mathrm{Na} / \mathrm{Cl}$ relationship.

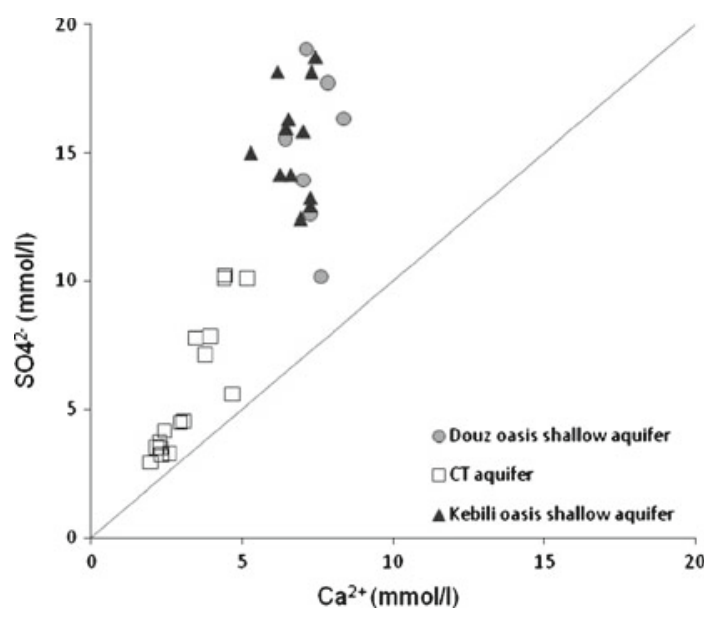

Figure $10 . \mathrm{Ca} / \mathrm{SO}_{4}$ relationship.

in inverse proportion (Garcia et al. 2001). In the absence of this exchange all data should plot to the origin (Mc Lean et al. 2000). We showed that majority of points are plotted near the origin which indicates that cation exchange is a secondary process in the mineralization.

Indeed, sulphate reveals positive correlation with chloride (figure 13) suggesting that any increase in $\mathrm{SO}_{4}^{2-}$ and $\mathrm{Cl}^{-}$across most of the aquifer is probably from a uniform source of gypsum anhydrite with some halite within water-bearing formations. However, we noticed a relative enrichment of the Douz oasis shallow aquifer samples with chloride indicating that the contribution of halite dissolution to the groundwater mineralization could be related to the effect of halite dissolution. This diagram also indicates enrichment with sulfates in the Kebili oasis shallow aquifers proving the effect of gypsum dissolution.

Saturation indices are used to evaluate the degree of equilibrium between water and minerals.

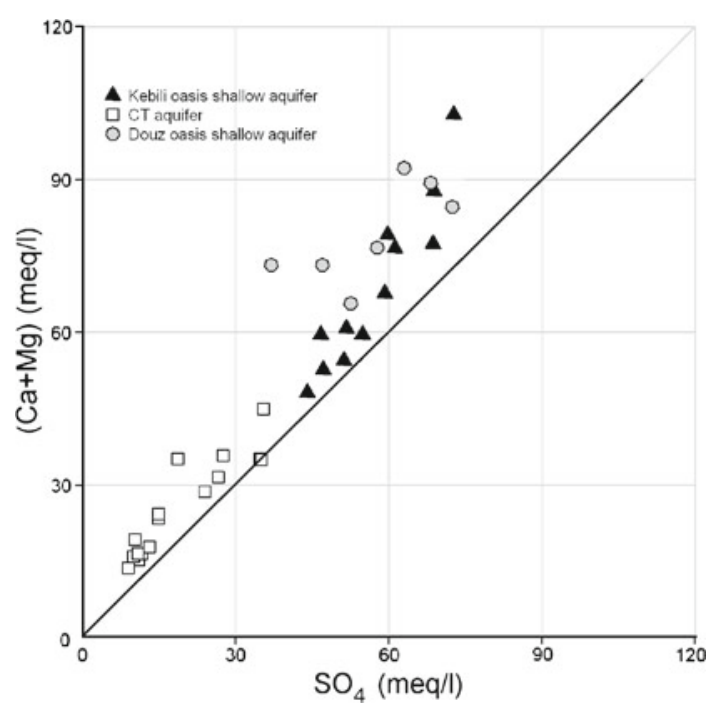

Figure 11. $(\mathrm{Ca}+\mathrm{Mg}) / \mathrm{SO}_{4}$ relationship.

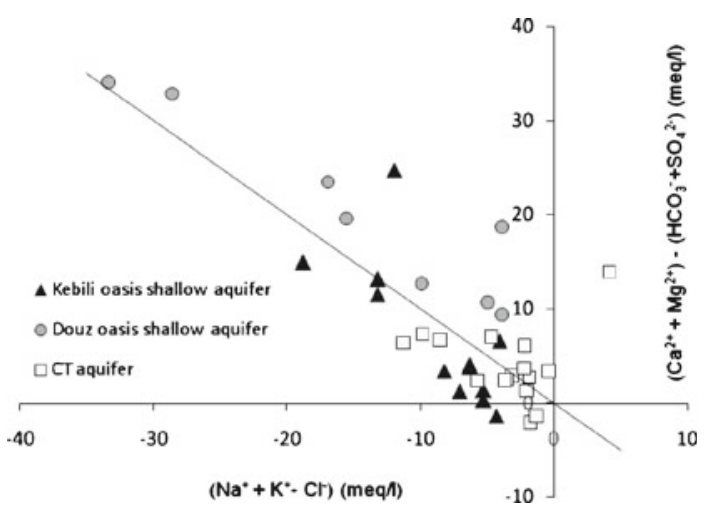

Figure 12. $(\mathrm{Na}+\mathrm{K}-\mathrm{Cl}) /(\mathrm{Ca}+\mathrm{Mg})-\left(\mathrm{HCO}_{3}+\mathrm{SO}_{4}\right)$ relationship.

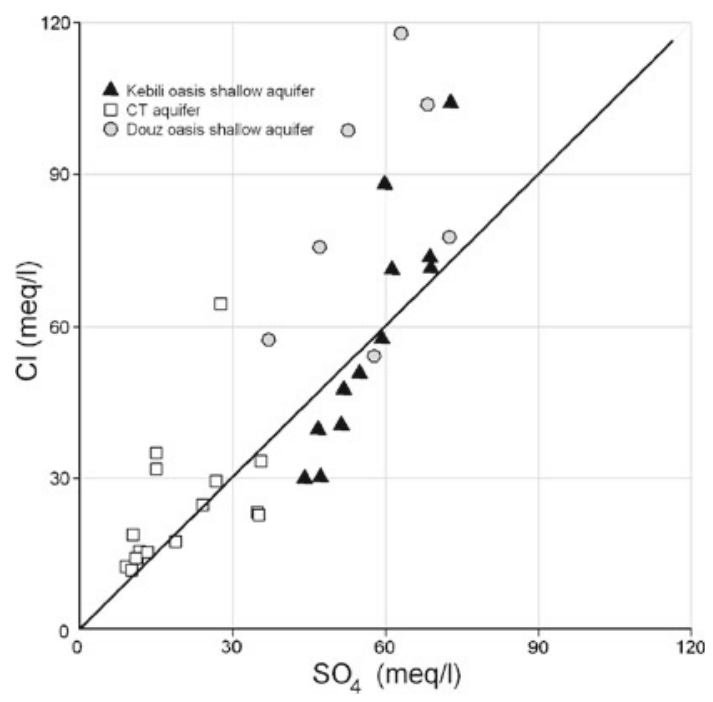

Figure 13. $\mathrm{SO}_{4} / \mathrm{Cl}$ relationship. 
Table 3. Saturation indices and isotopic data of the analyzed samples in the Nefzaoua region.

\begin{tabular}{|c|c|c|c|c|c|c|c|c|}
\hline $\begin{array}{l}\text { Sample } \\
\text { no. }\end{array}$ & SI anhyd. & SI arag. & SI cal. & SI dol. & SI gyp. & SI hal. & ${ }^{18} \mathrm{O} \%$ VSMOW & ${ }^{2} \mathrm{H} \%$ VSMOW \\
\hline $\mathrm{P} 1$ & -0.12 & 0.33 & 0.47 & 1.05 & 0.10 & -4.24 & & \\
\hline P3 & -0.28 & -0.04 & 0.10 & 0.32 & -0.07 & -4.48 & -4.37 & -43.25 \\
\hline $\mathrm{P} 4$ & -0.22 & 0.19 & 0.33 & 0.55 & 0.00 & -4.68 & -7.10 & -54.19 \\
\hline P5 & -0.20 & 0.16 & 0.31 & 0.25 & 0.02 & -4.97 & & \\
\hline $\mathrm{P} 6$ & -0.13 & 0.29 & 0.44 & 0.87 & 0.08 & -3.90 & & \\
\hline $\mathrm{P} 7$ & -0.18 & 0.22 & 0.36 & 1.06 & 0.03 & -4.18 & & \\
\hline $\mathrm{P} 8$ & -0.19 & 0.10 & 0.25 & 0.60 & 0.03 & -4.24 & & \\
\hline P9 & -0.18 & 0.20 & 0.34 & 0.74 & 0.04 & -4.08 & & \\
\hline $\mathrm{P} 11$ & -0.21 & 0.24 & 0.38 & 0.69 & 0.01 & -4.55 & & \\
\hline $\mathrm{P} 12$ & -0.20 & 0.38 & 0.52 & 0.86 & 0.02 & -4.67 & -5.89 & -48.20 \\
\hline $\mathrm{P} 13$ & -0.19 & 0.20 & 0.34 & 0.71 & 0.03 & -4.38 & -5.95 & -49.13 \\
\hline P14 & -0.16 & 0.21 & 0.35 & 0.39 & 0.06 & -4.99 & -5.62 & -44.12 \\
\hline $\mathrm{P} 15$ & -0.11 & -0.01 & 0.13 & 0.29 & 0.10 & -3.86 & & \\
\hline $\mathrm{P} 16$ & -0.12 & 0.38 & 0.53 & 1.05 & 0.09 & -3.80 & -6.08 & -47.84 \\
\hline $\mathrm{P} 17$ & -0.22 & -0.02 & 0.12 & 0.11 & 0.00 & -3.90 & -3.78 & -34.28 \\
\hline $\mathrm{P} 18$ & -0.29 & 0.16 & 0.31 & 0.60 & -0.08 & -4.60 & -5.74 & -46.96 \\
\hline P19 & -0.24 & 0.41 & 0.55 & 1.08 & -0.02 & -4.19 & -5.58 & -46.29 \\
\hline P20 & -0.11 & -0.01 & 0.14 & 0.36 & 0.10 & -4.13 & -1.86 & -25.89 \\
\hline $\mathrm{P} 21$ & -0.21 & 0.33 & 0.47 & 1.08 & 0.00 & -4.46 & -4.86 & -41.98 \\
\hline $\mathrm{P} 22$ & -0.03 & 0.03 & 0 & 0.50 & 0 & -3.33 & & \\
\hline $\mathrm{F} 1$ & -0.62 & -0.38 & -0.24 & -0.55 & -0.14 & -5.07 & -6.55 & -56.32 \\
\hline $\mathrm{F} 2$ & -1.05 & -0.52 & -0.37 & -0.71 & -0.83 & -5.32 & -6.4 & -55.9 \\
\hline F3 & -0.40 & 0.00 & 0.14 & 0.25 & -0.19 & -4.80 & -6.51 & -50.81 \\
\hline $\mathrm{F} 4$ & -1.07 & -0.35 & -0.21 & -0.39 & -0.86 & -5.51 & -6.82 & -55.72 \\
\hline F5 & -1.18 & -0.55 & -0.41 & -0.78 & -0.96 & -5.61 & -6.87 & -55.77 \\
\hline F6 & -1.08 & -0.41 & -0.27 & -0.53 & -0.86 & -5.62 & -6.92 & -51.37 \\
\hline F7 & -1.04 & -0.45 & -0.31 & -0.57 & -0.82 & -5.48 & -6.67 & -51.92 \\
\hline $\mathrm{F} 8$ & -1.06 & -0.52 & -0.38 & -0.72 & -0.84 & -5.52 & -6.68 & -54.71 \\
\hline F9 & -0.67 & -0.43 & -0.29 & -0.46 & -0.45 & -4.29 & & \\
\hline F10 & -0.89 & -0.46 & -0.31 & -0.63 & -0.67 & -4.82 & & \\
\hline F11 & -0.88 & -0.42 & -0.28 & -0.53 & -0.66 & -4.94 & & \\
\hline F12 & -0.44 & -0.21 & -0.06 & -0.20 & -0.22 & -5.09 & & \\
\hline F13 & -0.58 & -0.23 & -0.09 & -0.22 & -0.36 & -4.95 & & \\
\hline F14 & -0.43 & -0.52 & -0.38 & -0.84 & -0.22 & -5.11 & & \\
\hline F15 & -0.65 & -0.13 & 0.02 & -0.04 & -0.43 & -5.21 & & \\
\hline F16 & -0.97 & -0.43 & -0.28 & -0.53 & -0.75 & -5.50 & & \\
\hline $\mathrm{R} 1$ & -1.47 & -1.15 & -1.01 & -3.37 & -1.25 & -7.75 & -7.50 & -41.79 \\
\hline $\mathrm{R} 2$ & -2.53 & -1.95 & -1.81 & -4.48 & -2.31 & -8.88 & -8.67 & -60.93 \\
\hline R3 & -2.14 & -2.01 & -1.86 & -4.49 & -1.92 & -7.81 & -1.44 & -3.28 \\
\hline $\mathrm{R} 4$ & -2.28 & -2.13 & -1.98 & -4.87 & -2.06 & -8.92 & -2.50 & -2.43 \\
\hline $\mathrm{R} 5$ & -1.79 & -1.79 & -1.65 & -4.4 & -1.57 & -8.66 & -4.33 & -22.14 \\
\hline
\end{tabular}

Changes in saturation state are useful to distinguish different stages of hydrochemical reactions and are important in controlling water chemistry. The saturation indices for precipitation and the water groups are compiled in table 3 . The dissolution of evaporites is also confirmed by the saturation indices. They show that water is saturated with respect to calcite, aragonite and dolomite and undersaturated with respect to halite, anhydrite and gypsum (table 3). The saturation indices of halite and gypsum, vary in inverse proportion respectively to the sum of $\mathrm{Na}^{+}, \mathrm{Cl}^{-}$(figure 14a) and $\mathrm{Ca}^{2+}, \mathrm{SO}_{4}^{2-}$ (figure 14b) and confirm that the geochemical condition was dominated by the dissolution of anhydrite, gypsum and halite minerals.

Interrelations between major elements have been investigated by binary relationships. However, in order to refine the results, the correlation matrix is given in table 4 . We remarked that TDS is highly correlated to the $\mathrm{Na}^{+}, \mathrm{Ca}^{2+}, \mathrm{Mg}^{2+}, \mathrm{SO}_{4}^{2-}$ and $\mathrm{Cl}^{-}$with correlation coefficients respectively 

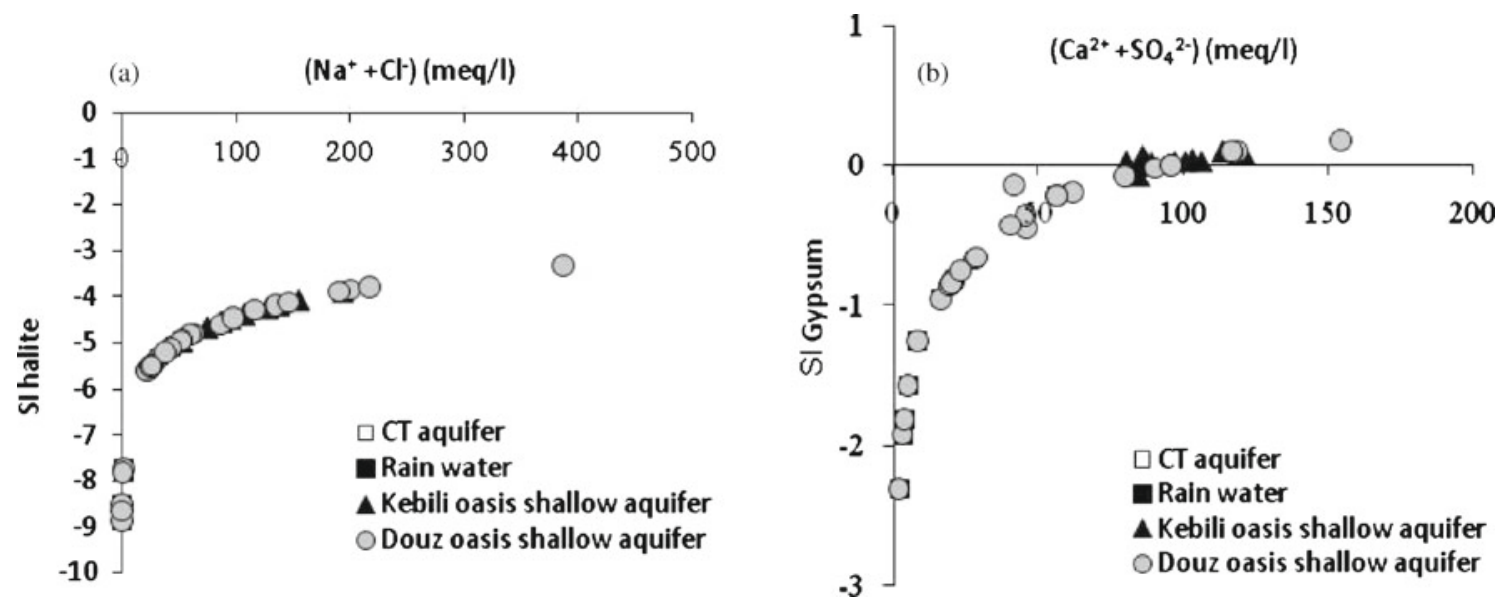

Figure 14. $(\mathrm{Na}+\mathrm{Cl}) / \mathrm{SI}$ halite relationship $(\mathbf{a})$ and $\left(\mathrm{Ca}+\mathrm{SO}_{4}\right) / \mathrm{SI}$ gypsum relationship (b).

Table 4. Correlation matrix for chemical parameters.

\begin{tabular}{lccccccccc}
\hline & $\mathrm{Cl}^{-}$ & $\mathrm{NO}_{3}^{-}$ & $\mathrm{SO}_{4}^{2-}$ & $\mathrm{HCO}_{3}^{-}$ & $\mathrm{Na}^{+}$ & $\mathrm{K}^{+}$ & $\mathrm{Mg}^{2+}$ & $\mathrm{Ca}^{2+}$ & $\mathrm{TDS}$ \\
\hline $\mathrm{Cl}^{-}$ & 1 & & & & & & & & \\
$\mathrm{NO}_{3}^{-}$ & -0.31 & 1 & & & & & & & \\
$\mathrm{SO}_{4}^{2-}$ & 0.85 & -0.49 & 1 & & & & & & \\
$\mathrm{HCO}_{3}^{-}$ & 0.49 & -0.31 & 0.73 & 1 & & & & & \\
$\mathrm{Na}^{+}$ & 0.99 & -0.37 & 0.86 & 0.48 & 1 & & & & \\
$\mathrm{~K}^{+}$ & 0.79 & -0.42 & 0.76 & 0.28 & 0.81 & 1 & & \\
$\mathrm{Mg}^{2+}$ & 0.91 & -0.35 & 0.94 & 0.68 & 0.90 & 0.73 & 1 & & \\
$\mathrm{Ca}^{2+}$ & 0.87 & -0.37 & 0.96 & 0.76 & 0.86 & 0.71 & 0.91 & 1 & \\
$\mathrm{TDS}$ & 0.97 & -0.39 & 0.94 & 0.63 & 0.97 & 0.79 & 0.96 & 0.94 & 1 \\
\hline
\end{tabular}

of $0.97 ; 0.94 ; 0.96 ; 0.94$; and 0.97 indicating that all these major elements are contributing to the mineralization and confirm the TDS/major elements relationships. We also noticed a high correlation between $\mathrm{Na}^{+}-\mathrm{Cl}^{-} ; \mathrm{Ca}^{2+}-\mathrm{SO}_{4}^{2-}$ and $\mathrm{Mg}^{2+}-\mathrm{SO}_{4}^{2-}$ with respective correlation coefficients of $0.99 ; 0.96$ and 0.94 highlighting influence of dissolution of evaporite minerals.

According to the variation in the ratio of $\mathrm{Na}^{+} /$ $\left(\mathrm{Na}^{+}+\mathrm{Ca}^{2+}\right)$ as a function of TDS in the water chemistry diagram, chemical data of water sample points towards evaporation dominance zone (figure 15). This diagram is used to assess the functional sources of dissolved ions like precipitation dominance, rock dominance and evaporation dominance controlling the water chemistry (Gibbs 1970). The climatic conditions, with arid to semi-arid climate, increase the evaporation rate contributing to the concentrations of ions and thus TDS.

\subsection{Isotopic tools}

The environmental isotopes ${ }^{18} \mathrm{O}$ and hydrogen ${ }^{2} \mathrm{H}$ are effective tools to determine the origin of groundwater and largely useful to study the groundwater recharge, migration pathways and mixing of waters from different sources (Fontes 1976; Subyani 2004). The results of the isotopic study were presented in table 3 . The efficiency of these isotopes is widely proved when used in relation with the chloride concentrations. The $\delta^{18} \mathrm{O} / \delta^{2} \mathrm{H}$ diagram (figure 16) shows the position of all samples relative to the Global Meteoric Water Line (GMWL : $\delta^{2} \mathrm{H}=8 \delta^{18} \mathrm{O}+10$ ), (Craig 1961) and the Local Meteoric Water Line of Sfax (LMWL : $\delta^{2} \mathrm{H}=8 \delta^{18} \mathrm{O}+13,5$ ), (Maliki 2000; Celle et al. 2001). All the groundwater samples of the oasis and the CT aquifer are located largely below the GMWL and the LMWL indicating their old origin, probably in relation to humid periods of the Pleistocene. Precipitation points are plotted along the meteoric water lines with a same range d-excess. The continentality effect does not appear here although the region is situated far from the sea. Precipitation fingerprint in the oasis shallow aquifers could therefore be considered as of the Sfax station.

The deep groundwater samples of the CT reveal a relatively constant composition with an average of $-6.67 \%$ V-SMOW for the oxygen 18 and $-54.06 \%$ V-SMOW for the deuterium. They 


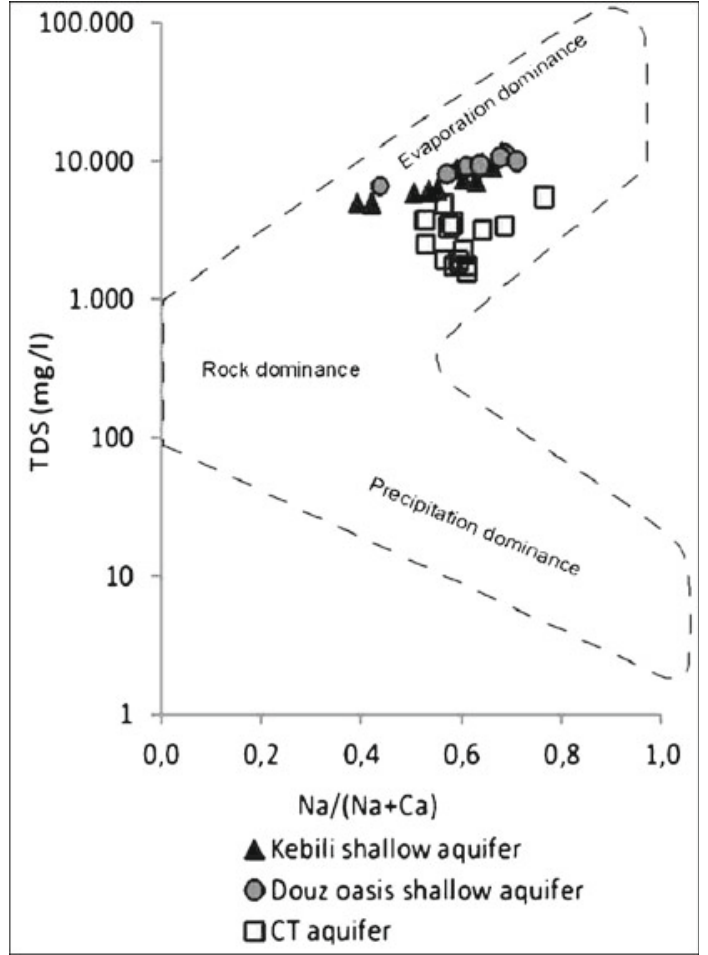

Figure 15. Gibbs diagram of the analyzed groundwaters.

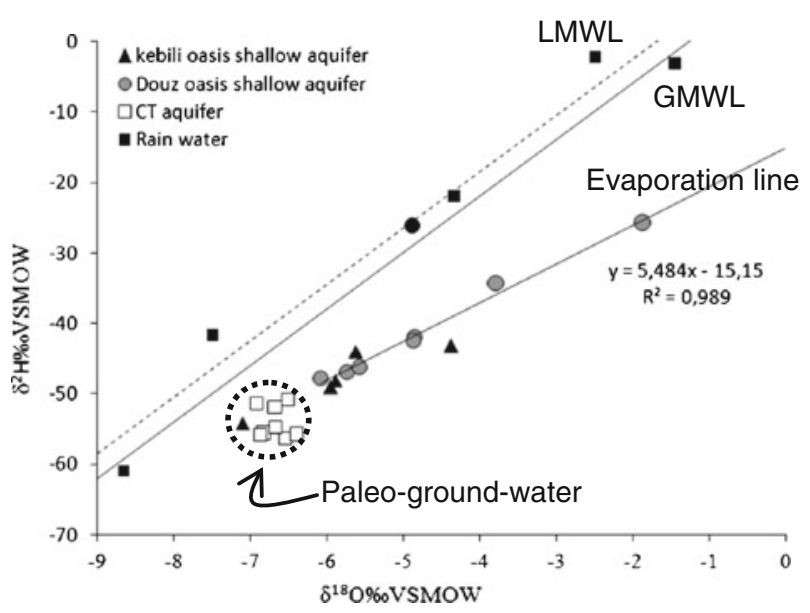

Figure 16. $\delta^{18} \mathrm{O} / \delta^{2} \mathrm{H}$ relationship.

constitute a depleted group indicating cooler temperature during recharge related to Pleistocene and Holocene humid periods (Edmunds et al. 1997). The $\delta^{18} \mathrm{O}$ and $\delta^{2} \mathrm{H}$ contents of the oasis shallow aquifers show a wide range of variation from -6.08 to $-1.86 \%$ V-SMOW and from -49.13 to $-25.89 \%$ V-SMOW respectively. They constitute the enriched waters and fall on a line with a slope of 5.4 intercepting with the groundwater group and indicating an evaporation effect (figure 16). Nevertheless, we show that $\mathrm{P} 4$ presents a depleted $\delta^{18} \mathrm{O}$

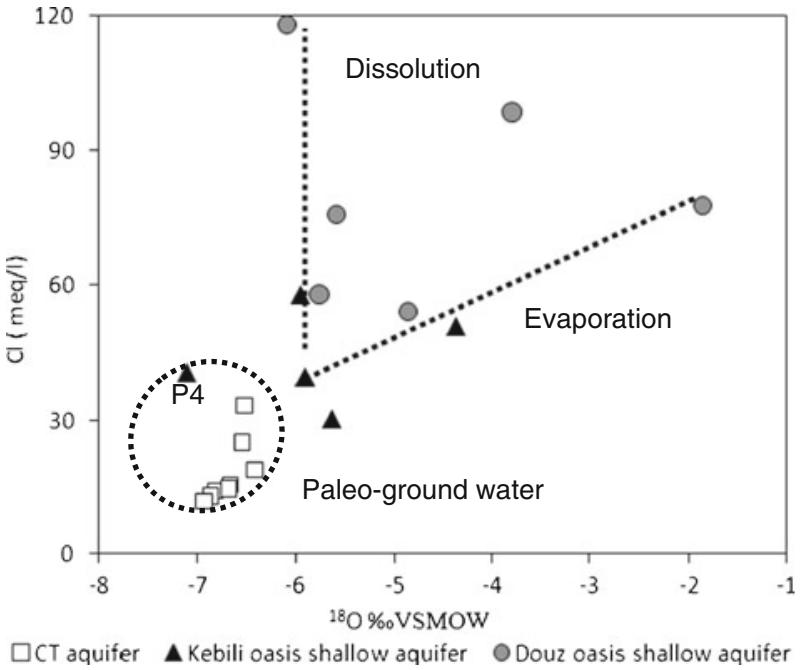

Figure 17. $\delta^{18} \mathrm{O} / \mathrm{Cl}$ relationship.

and $\delta^{2} \mathrm{H}$ composition with $-7.01 \% \mathrm{~V}$-SMOW and $-54.71 \%$ V-SMOW respectively. This depletion may be related to an upwelling of ancient water from the underlying aquifers of the $\mathrm{CT}$ or the CI. The referred evaporation line coincides practically with the mixing line of the CT and the Plio-Quaternary aquifers. The reason behind this coincidence is the common old origin of these groundwaters (Zouari 1988; Mamou 1990; Edmunds et al. 1997; Zouari et al. 2003; Abid et al. 2011). In fact, the main recharge source of the Plio-Quaternary aquifers is insured by the return flow of irrigation waters from the underlying aquifer of the CT.

The importance of dissolution of evaporites (halite, anhydrite and/or gypsum) and evaporation processes are observed in the $\mathrm{Cl}^{-}$versus $\delta^{18} \mathrm{O}$ diagram (figure 17) which includes data for groundwater collected in this area. It is noticed that the major part of the groundwater concentrations are not clearly correlated with the oxygen- 18 contents. This heterogeneous arrangement seems to be mainly due to the dissolution of evaporite deposits. Nevertheless, some samples show a clear tendency of chloride and oxygen 18 increases indicating that evaporation is an important process, in particular, for near surface groundwater samples.

\section{Conclusion}

Investigations have been based on three approaches: i) Electrical Resistivity Tomography, ii) geochemical tools using major elements, distribution and relationships, and iii) isotopic tools. The electrical tomography was used to provide insight into the regional factors and processes controlling the chemical composition and groundwater's salinity degree in the study area. In addition, hydrochemical and 
isotopic analyses were applied to the geochemical dataset. The combination of these various methods allowed identifying and refining mineralization processes taking place in oasis shallow aquifers in relation with natural conditions and also with local irrigation practices as submersion irrigation and drainage basin.

The investigations have highlighted the influence of the high salinity drainage water on the local oasis aquifers. The risk of hypersaline waters intrusion into shallow aquifers enhances the vulnerable situation of water resources in this region.

Electrical tomography surveys provide further information about the water quality of the various formations. These results showed that the low resistivity values are related to an intrusion of salt water from the drainage basin in the Douz region while, it could be explained by an increasing of clay content in the Kebili region.

The salinity of the Plio-Quaternary aquifers is very heterogeneous. It is relatively more elevated in the Douz region in relation to the proximity of drainage basins. The water type characteristics indicate that Douz oasis shallow aquifer is influenced by the drainage water and the Kebili oasis shallow aquifer has a mixed facies as the CT aquifer. The analysis of water chemical characteristics revealed that the observed mineralization is primarily linked to the dissolution of evaporites, with significant contribution of secondary processes such as evaporation and/or cation exchange with clay minerals. The saturation indices accounted for the precipitation and dissolution mechanism that occurred in the Plio-Quaternary aquifers. The Gibbs diagram indicate that evaporation also constitute a major process in the mineralization.

Isotopic data $\left({ }^{18} \mathrm{O},{ }^{2} \mathrm{H}\right)$ indicated the old origin of the shallow waters in the Kebili and Douz regions highlighting that these near surface systems are mainly recharged by the return flow of irrigation waters withdrawn from the underlying deep aquifer of the Complex Terminal. These stable isotopes are effective to more indicate the role of the evaporation and dissolution as main processes controlling the salinization.

\section{References}

Abid K, Hadj Ammar F, Chkir N and Zouari K 2011 Relationship between Senonian and deep aquifers in southern Tunisia; J. Quat. Int. 257 13-26.

Appelo C A J and Postma D 1993 Geochemistry Groundwater and Pollution; A A Balkema, Rotterdam.

Atekwana E A, Sauck W A and Werkema D D 2000 Investigations of geoelectrical signatures at a hydrocarbon contaminated site; J. Appl. Geophys. 44(2-3) 167-180.

Bauer P, Supper R, Zimmermann S and Kinzelbach W 2006 Geoelectrical imaging of groundwater salinization in the Okavango Delta, Botswana; J. Appl. Geophys. 60 126-141.

Beauvais A, Ritz M, Parisot J C, Dukhan M and Bantsimba C 1999 Analysis of poorly stratified lateritic terrains overlying a granitic bedrock in West Africa using a 2-D electrical resistivity tomography; Earth Planet. Sci. Lett. 173 413-424.

Ben Hamouda M F, Tarhouni J, Leduc C and Zouari K 2010 Understanding the origin of salinization of the PlioQuaternary eastern coastal aquifer of Cap Bon (Tunisia) using geochemical and isotope investigations; J. Environ. Earth Sci., doi: 10.1007/s12665-010-0758-1.

Bennetts D A, Webb J A, Stone D J M and Hill D M 2006 Understanding the salinisation process for groundwater in an area of south-eastern Australia using hydrochemical and isotopic evidence; J. Hydrol. 323 178-192.

Benson A K, Payne K L and Stubben M A 1996 Mapping groundwater contamination using dc resistivity and VLF geophysical methods - a case study; Geophysics 62(1) 80-86.

Bevc D and Morrison H F 1991 Borehole to surface electrical resistivity monitoring of a salt water injection experiment; Geophys. 56 769-777.

Brouste L, Marlin C and Dever L 1997 Geochemistry and residence time estimation of groundwater from the upper aquifer of the Chihuahua desert (Comarca Lagunera, Northern Mexico); J. Appl. Geochem. 12 775-786.

Celle H, Zouari K, Travi Y and Daoud A 2001 Caractérisation isotopique des pluies en Tunisie. Essaie de typologie dans la région de Sfax; CR Acad. Sci. Paris 6 625-631.

Craig H 1961 Isotopic variations in meteoric water; Science 133 1702-1703.

De Franco R, Biella G, Tosi L, Teatini P, Lozej A, Chiozzotto B, Giada M, Rizzetto F, Claude C, Mayer A, Bassan V and Gasparetto-Stori G 2009 Monitoring the saltwater intrusion by time lapse electrical resistivity tomography: The Chioggia test site (Venice Lagoon, Italy); J. Appl. Geophys. 69 117-130.

De la Vega M, Osella A and Lascanon E 2003 Joint inversion of Wenner and dipole-dipole data to study a gasoline-contaminated soil; J. Appl. Geophys. 54(1-2) 97-109.

Edmunds W M, Shand P, Guendouz A H, Moulla A S, Mamou A and Zouari K 1997 Recharge characteristics and groundwater quality of the Grand Erg Oriental basin; British Geol. Soc. London, UK.

Edwards L S 1977 A modified pseudosection for resistivity and induced-polarization; Geophysics 42(5) 1020-1036.

El-Fahem T 2003 Salinisation of groundwater in the Nefzaoua Oases: South Tunisia, Institute of Hydromechanics and Water Resources Management; Thesis in geology, Swiss Federal Institute of Technology, Zürich.

El Yaouti F, El Mandour A, Khattach D, Benavente J and Kaufmann O 2008 Salinization processes in the unconfined aquifer of Bou-Areg (NE Morocco): A geostatistical, geochemical, and tomographic study; J. Appl. Geochem. 24 16-31.

Fedregoni L, Krimissa M, Zouari K, Maliki A and Zuppi G M 2001 Origine de la minéralisation et comportement hydrogéochimique d'une nappe phréatique soumise à des contraintes naturelles et anthropiques sévères: Exemple de la nappe de Djebeniana (Tunisie); Journal des Géosciences de Surface, C. R. Acad. Sci. Paris, Sciences de la Terre et des planètes 332 665-671.

Fontes J C 1976 Isotopes du milieu et cycle des eaux naturelles: quelques aspects; Ph.D. thesis, University of Paris VI, 208p. 
Garcia M G, Del Hidalgo M and Blesa M A 2001 Geochemistry of groundwater in the alluvial plain of Tucuman province Argentina; J. Hydrol. 9 597-610.

Gibbs R J 1970 Mechanisms controlling world water chemistry; Science 17 1088-1090.

Gueddari M 1980 Géochimie des sels et des saumures du Chott el Djérid [Geochemistry of salts and brines from the Chott el Djerid], Univ. de Paul Sabatier, Toulouse, France.

Grassi S, Cortecci G and Squarsi P 2007 Groundwater resource degradation in coastal plains: The example of the Cecina area (Tuscany - Central Italy); J. Appl. Geochem. 22 2273-2289.

Griffiths D H and Barker R D 1993 Two-dimensional resistivity imaging and modeling in areas of complex geology; J. Appl. Geophys. 29 211-226.

Kacimov A R and Obnosov Y V 2006 Strip-focused phreatic surface flow driven by evaporation: Analytical solution by the Riesenkampf function; J. Adv. Water Resour. 29 1565-1571.

Kemna A, Vanderborght J, Kulessa B and Vereecken $\mathrm{H}$ 2002 Imaging and characterisation of subsurface solute transport using electrical resistivity tomography (ERT) and equivalent transport models; J. Hydrol. 267(3-4) $125-146$.

Kruse S E, Brudzinski M R and Geib T L 1998 Use of electrical and electromagnetic techniques to map seawater intrusion near the Cross-Florida Barge Canal; J. Environ. Eng. Geosci. 4(3) 331-340.

Loke M H 1999 RES2DINV-Rapid 2D Resistivity and IP Inversion using the Least-Squares Method: Software Manual; Advanced Geosci., Austin, TX.

Maliki M A 2000 Etude hydrogéologique, hydrochimique et isotopique du système aquifère de Sfax, Tunisie [Hydrogeological, hydrochemical and Isotopic study of the Sfax aquifer system, Tunisia]; Ph.D thesis, University of Tunis I, Tunis.

Mamou A 1979 Contribution à l'étude hydrogéologique de la presqu'île de Kébili; thèse Doctorat $3^{\text {ème }}$ cycle. $107 \mathrm{p}$.

Mamou A 1990 Caractérisatiion et évaluation des ressources en eau du sud Tunisien [Characteristics and evaluation of the water resources in southern Tunisia]; Ph.D thesis, Université du Paris-Sud Centre d'Orsay, Paris.

Matthew J L and Keith L B 2010 Understanding subsurface solute distributions and salinization mechanisms in a tropical coastal floodplain groundwater system; J. Hydrol. 390 131-142.

Mc Lean W, Jankowski J and Lavitt N 2000 Groundwater quality and sustainability in an alluvial aquifer. Australia; In: Groundwater, past achievement and future challenges (eds) Sielilo et al., Balkema, Rotterdam, pp. 567-573.

Nowroozi A A, Horrocks S B and Henderson P 1999 Saltwater intrusion into the freshwater aquifer in the eastern shore of Virginia: A reconnaissance electrical resistivity survey; J. Appl. Geophys. 42(1) 1-22.

Osiensky J L and Donaldson P R 1995 Electrical flowthrough an aquifer for contaminant source leak detection and delineation of plume evolution; J. Hydrol. 169(1-4) 243-263.

Stigter T Y, Van Ooijen S P J, Post V E A, Appelo C A and Carvalho Dill A M M 1998 A hydrogeological and hydrochemical explanation of the groundwater composition under irrigated land in a Mediterranean environment, Algarve, Portugal; J. Hydrol. 208 262-279.

Savin C, Robineau B, Monteil G, Beauvais A, Parisot J C and Ritz M 2002 Electrical imaging of peridotite weathering mantles as complementary tools for a nickel ore exploration in New Caledonia; Proceedings of the 16th ASEG Geophysical Conference, Adelaide.

Subyani A M 2004 Use of chloride-mass balance and environmental isotopes for evaluation of groundwater recharge in the alluvial aquifer, Wadi Tharad, west Saudi Arabia; Environ. Geol. 46 741-749.

Seigfried T 2004 Optimal Utilization of a Non-Renewable Transboundary Groundwater Resource -Methodology, Case Study and Policy Implications, Ph.D thesis in the Swiss Federal Institute of Technology, Zurich.

White P A 1988 Measurement of groundwater parameters using saltwater injection and surface resistivity; Ground Water 26(2) 179-186.

Zammouri M, Seigfried T, El-Fahem T, Kriaa S and Kinzelbach W 2007 Salinization of groundwater in the Nefzaoua oases region, Tunisia: Results of a regional-scale hydrogeologic approach; Hydrogeol. J. 15 1357-1375.

Zouari K 1988 Géochimie et sédimentologie des dépôts continentaux d'origine aquatique du Quaternaire supérieur du Sud. Tunisien, Ph.D thesis, University of Paris-Sud Orsay.

Zouari K, Chkir N and Ouda B 2003 Palaeoclimatic variation in Maknassi basin (central Tunisia) during Holocene period using pluridisplinary approaches, IAEA Tech. Report 80-88, IAEA, Vienna. 